\title{
SERUM FACTORS OF ACQUIRED HEMOLYTIC ANEMIA IN LEUKEMIA AND LYMPHOMA *
}

\author{
By JEROME I. BRODY † AND STUART C. FINCH
}

(From the Department of Internal Medicine, Yale University School of Medicine, New Haven, Conn.)

(Submitted for publication June 3, 1960; accepted September 30, 1960)

The purpose of this study was to determine whether the abnormal serum factors of acquired hemolytic anemia in patients with leukemia and lymphoma could be characterized as antibody by the immune adherence technique. The pathogenesis of this disorder has not been completely explained and it was felt that the study of specific immunologic reactions might help to determine whether these serum factors are erythrocyte antibody. The technique of immune adherence $(1,2)$ was used not only because its flexibility and sensitivity make it most suitable for the study of antigen-antibody reactions but particularly because, insofar as is at present known, immune adherence will not occur unless antigen and specific complement-fixing antibody are present. The basic premise of this reaction states that in the presence of antigen, specific antibody, complement, and indicator (either primate red cells or nonprimate platelets), the antigen will adhere to the indicator particles. Immune adherence may be determined either macroscopically by red cell floccule formation or microscopically by dark-field illumination.

\section{METHODS AND MATERIALS}

\section{A. Patient group}

Serum samples taken from a total of 7 patients with acquired hemolytic anemia, ranging in age from 45 to 75 years, were studied. Two of the patients had lymphocytic lymphoma, 1 had Hodgkin's disease, 2 had chronic lymphocytic leukemia, 1 had acute monocytic leukemia and 1 had multiple myeloma. One patient with lymphoma had been treated with X-ray, nitrogen mustard, adrenocortical steroids and blood transfusions. Blood trans-

* This investigation was supported by a research grant (H-1577 C5) of the U. S. Public Health Service. Presented in part to the Fifty-Second Annual Meeting of the American Society for Clinical Investigation (Section IV, Hematology), Atlantic City, N. J., May 1, 1960.

† Formerly U. S. Public Health Research Fellow. Present address: Veterans Administration Hospital, Coral Gables, Fla. fusions also were given to the patient with multiple myeloma. None of the other patients received either tumor therapy or blood transfusions.

\section{B. Tests for sensitization}

Direct and indirect antiglobulin tests were performed as described by Coombs, Mourant and Race (3) and Jandl and Castle (4). Both the antihuman globulin and patient serums were used at full strength only and neither direct nor indirect Coombs titers were determined.

\section{Preparation of reactants}

1. Indicator. Guinea pig platelets were used as indicator particles. They were collected and handled as described by Nelson and Nelson (5). Eight $\mathrm{ml}$ of Alsever's solution, previously chilled in ice, was drawn into a $20 \mathrm{ml}$ syringe which had been kept in a freezer for 30 minutes. Eight $\mathrm{ml}$ of cardiac blood from a $500 \mathrm{~g}$ guinea pig was aspirated directly into the ice-cold solution. The blood then was transferred to a $30 \mathrm{ml}$, iced, Pyrex test tube. All centrifugation was done at $0^{\circ} \mathrm{C}$. The blood-Alsever's solution was centrifuged at $80 \mathrm{G}$ for 30 minutes. The supernatant was removed carefully with a capillary pipet and transferred to a $40 \mathrm{ml}$ lipped, round-bottom tube and centrifuged at $900 \mathrm{G}$ for 20 minutes. The supernatant again was removed and discarded. The platelet button was resuspended by gentle agitation and the dropwise addition of $5 \mathrm{ml}$ of cold Alsever's solution. The spinning and washing were repeated twice. The platelet button finally was resuspended in $2 \mathrm{ml}$ gelatin veronal buffer (GVB) and centrifuged at $35 \mathrm{G}$ for 5 minutes in order to remove any platelet clumps. This method resulted in minimal platelet clumping and gave relatively homogeneous platelet suspensions. The supernatant fluid, containing only platelets, was standardized to 50 per cent transmission on a Beckman DU spectrophotometer at a wave length of $400 \mathrm{~m} \mu$.

2. Antigen. Normal, type $\mathrm{O}, \mathrm{Rh}$ negative erythrocytes, both unsensitized and sensitized with patient serum, and Coombs positive patient erythrocytes were used as antigen. The blood was collected directly into Alsever's solution ( $2 \mathrm{ml}$ Alsever's to $1 \mathrm{ml}$ whole blood) and was either used the same day or stored at $4^{\circ} \mathrm{C}$ for a maximum of 48 hours. In the latter instance, $250 \mathrm{U}$ of aqueous penicillin $\mathrm{G}$ per $\mathrm{ml}$ blood-Alsever's solution was added to inhibit bacterial growth. The red cells were washed three times with GVB and made up to a 2 per cent solution in GVB. In this assay they were used 
TABLE I

Checkerboard titration in immune adherence

\begin{tabular}{|c|c|c|c|c|c|c|}
\hline \multicolumn{2}{|c|}{ Antigen* } & \multicolumn{5}{|c|}{ Antibody $\dagger$ dilution } \\
\hline Concentration & Dilution & $1: 100$ & $1: 200$ & $1: 400$ & $1: 800$ & $1: 1,600$ \\
\hline $\begin{array}{l}\% \\
2 \\
2 \\
2\end{array}$ & $\begin{array}{c}\text { Undiluted } \\
1: 2 \\
1: 4\end{array}$ & $\begin{array}{r}+2 \\
+1 \\
0\end{array}$ & $\begin{array}{r}+3 \\
+1 \\
0\end{array}$ & $\begin{array}{l}+4 \\
+2 \\
+1\end{array}$ & $\begin{array}{l}+3 \\
+3 \\
+1\end{array}$ & $\begin{array}{r}+2 \\
+1 \\
0\end{array}$ \\
\hline
\end{tabular}

* Human, type A erythrocytes.
† Homologous, type A antiserum.

undiluted at 2 per cent, and at dilutions of $1: 2$ and $1: 4$ of the 2 per cent suspension with GVB.

3. Complement. Normal, human, type $\mathrm{AB}, \mathrm{Rh}$ negative serum was used as the complement source. It was kept at $-70^{\circ} \mathrm{C}$ in $1-\mathrm{ml}$ aliquot portions in screw-top vials. After quick thawing it was used in a constant dilution of $1: 40$ with GVB.

4. Antibody. In order to determine the suitability of the immune adherence (IA) technique for the detection of erythrocyte antibody, heterologous typing serums such as anti-M and anti-N were used as antibody source in dilutions of $1: 100$ and $1: 1,600$. Human, type-specific anti-A and anti-B serums of the natural and immune type and both agglutinating and incomplete (nonagglutinating) anti- $\mathrm{Rh}_{0}$ (D) serums were used as homologous antibody in the same dilutions. An initial dilution of 1: 100 was used because, except for the incomplete anti$\mathrm{Rh}_{0}$ (D) serum, in dilutions below this concentration, the red cells were agglutinated spontaneously by the antiserums. In an analogous manner, patient serums and a broad-spectrum antihuman globulin ${ }^{1}$ were used as antibody source in dilutions of $1: 10$ to $1: 160$. This dilution range was employed because it afforded optimal reactivity in the assay. Conventional agglutination titers were not performed on the individual antiserums.

\section{Performance of the assay}

All reactants were kept at $0^{\circ} \mathrm{C}$ in crushed ice prior to their combination. Screw-top vials with a $2 \mathrm{ml}$ capacity

${ }^{1}$ Supplied by the Ortho Pharmaceutical Corporation, Raritan, N. J.

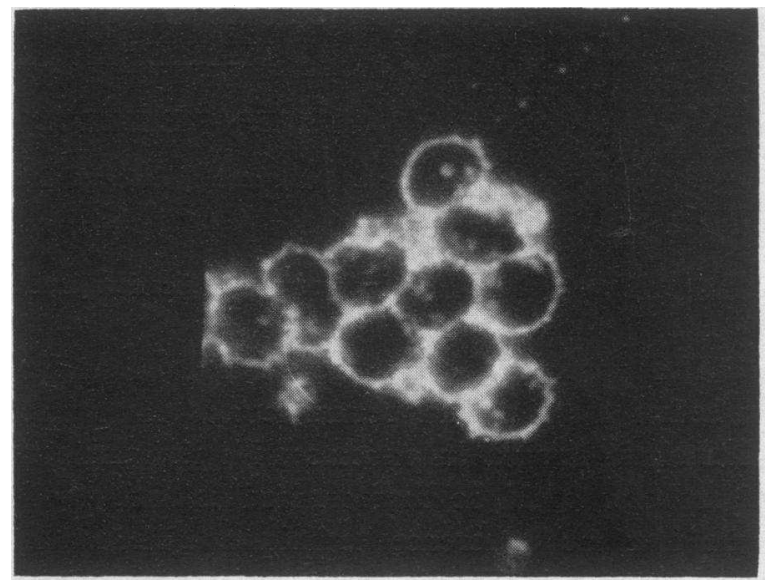

Fig. 1. A positive IMmUNe ADHERENCE REACtion UNDER DARK-FIELD MICROSCOPY. The erythrocytes are adherent to the guinea pig platelets which are seen as luminescent particles between the red cells $(\times 450)$.

were used in the test. Regardless of its source, $0.25 \mathrm{ml}$ of antibody in the dilutions noted previously was added slowly to $0.25 \mathrm{ml}$-aliquots of each red cell dilution (antigen) so that a checkerboard pattern titration resulted. This type of titration was constructed because optimal reactivity in IA is dependent in large part upon the relative concentrations of antigen and antibody. The vials were rotated at $6 \mathrm{rpm}$ in a $37^{\circ} \mathrm{C}$ incubator for 10 minutes. Upon removal, $0.5 \mathrm{ml}$ of chilled complement (1:40 dilution) was added to the antigen-antibody mixture in each vial. The 10 minute incubation, with slow rotation, was repeated and $0.1 \mathrm{ml}$ of the indicator platelet suspension then was added to each vial. The vials were rotated at $37^{\circ} \mathrm{C}$ for 40 minutes and removed from the incubator. Wet coverslip preparations, made by placing one drop of the incubation mixture on a glass slide, were examined microscopically under dark-field illumination. IA of the red cells to the platelets indicated the presence of erythrocyte antibody. The reaction was read as negative when no red cells were adherent to the platelets, as a trace when less than 10 per cent of the red cells adhered to the

TABLE II

Type-specific erythrocyte immune adherence reactions

\begin{tabular}{|c|c|c|c|c|c|c|}
\hline \multirow[b]{2}{*}{ Antigen } & \multirow[b]{2}{*}{ Antibody } & \multicolumn{5}{|c|}{ Antibody dilution } \\
\hline & & $1: 100$ & $1: 200$ & $1: 400$ & $1: 800$ & $1: 1,600$ \\
\hline M erythrocytes & Heterologous anti-M & +2 & +2 & +4 & +3 & +2 \\
\hline $\mathrm{N}$ erythrocytes & Heterologous anti-N & +2 & +4 & +3 & +2 & +2 \\
\hline A erythrocytes & Homologous anti-A & +2 & +3 & +4 & +3 & +2 \\
\hline B erythrocytes & Homologous anti-B & +2 & +3 & +4 & +3 & +2 \\
\hline \multirow[t]{2}{*}{$\mathrm{Rh}_{0}$ (D) erythrocytes } & $\begin{array}{l}\text { Homologous anti- } \mathrm{Rh}_{0}(\mathrm{D}) \\
\text { Agglutinating } \\
\text { Incomplete }\end{array}$ & +2 & +2 & +4 & +2 & +2 \\
\hline & (nonagglutinating) & +1 & +1 & +2 & +1 & 0 \\
\hline
\end{tabular}


platlets, +1 when there was IA of 10 to 25 per cent of the red cells, +2 with IA of 25 to 50 per cent of the red cells, +3 with IA of 50 to 75 per cent of the red cells, and +4 with IA of more than 75 per cent of the erythrocytes. An example of this type of titration is illustrated in Table I.

\section{RESULTS}

A. Tests for erythrocyte sensitiation. All patients except the one with Hodgkin's disease had positive direct and indirect antiglobulin reactions. There was good agreement between the antihuman globulin (3) and the polyvinylpyrrolidone (4) tests in these patients.

$B$. IA antibody assays. IA occurred when heterologous anti-M and anti-N and homologous anti-A, anti-B and both types of anti-Rh $\mathrm{h}_{0}$ (D) serums were reacted with erythrocytes of the appropriate antigenic structure (Figure 1). Except for anti-N and incomplete anti- $\mathrm{Rh}_{0}(\mathrm{D})$, the reactions were +4 at dilutions of $1: 400$ and +2 at dilutions of $1: 1,600$ in both the heterologous and homologous titrations. Dilutions of anti-N sera revealed $\mathrm{a}+4$ reaction at $1: 200$ and +2 at $1: 800$. The incomplete (nonagglutinating) anti- $\mathrm{Rh}_{0}$ (D) serum from a sensitized female gave $a+2$ IA reaction in serum dilutions of up to $1: 400$. Control tubes lacking either complement or antibody were negative for IA. These results are summarized in Table II. IA did not occur when patients' serums were reacted with their own erythrocytes or when untransfused patient serum was reacted with normal erythrocytes. In the patient with Hodgkin's disease, who had negative direct and indirect Coombs reactions, IA did not occur in any of the antigen-antibody combinations employed. However, when the serums of the two patients who had been repeatedly transfused were reacted with normal red cells, IA $(+2)$ did occur in dilutions of $1: 160$. IA was also noted when antihuman globulin was reacted with serum-sensitized normal and Coombs positive patient erythrocytes. The patterns in these assays revealed $\mathrm{a}+4$ reaction at a $1: 40$ dilution and $\mathrm{a}+1$ at a $1: 160$ dilution. Control tubes lacking antibody or complement were negative. These results are summarized in Table III.

\section{DISCUSSION}

The occurrence of IA when type-specific heterologous and homologous antiserums were reacted with appropriate erythrocytes indicates that this method is a sensitive indicator for the detection of natural and immune erythrocyte antibody. The increased sensitivity of IA as compared to conventional agglutination techniques permitted demonstration of antibody titers up to a dilution of at least $1: 1,600$. Maximum anti- $\mathrm{N}$ titers in a dilution of only $1: 800$ may depend on the diminished antigenicity of the $\mathrm{N}$ substance when compared to other blood-group factors. The most significant observation of this study was the absence of IA when serum from patients with acquired hemolytic anemia was reacted with either their own or normal erythrocytes. This indicated that a specific antigen-antibody reaction did not occur and that erythrocyte antibody was not present in these patients as measured by the IA technique, despite positive direct and indirect Coombs antiglobulin reactions. The test originally described by Coombs, Mourant and Race (6) was a new one for the detection of "incomplete" Rh agglutinins. Subsequently, other laboratory methods have been devised to demonstrate possible erythrocyte sen-

TABLE III

Erythrocyte immune adherence in acquired hemolytic anemia $(A H A)$

\begin{tabular}{llrrrrr}
\hline \multicolumn{1}{c}{ Antigen } & \multicolumn{1}{c}{ Antibody dilution } \\
\cline { 3 - 6 } & \multicolumn{1}{c}{ Antibody } & $1: 10$ & $1: 20$ & $1: 40$ & $1: 80$ & $1: 160$ \\
\hline AHA erythrocytes & AHA serum & 0 & 0 & 0 & 0 & 0 \\
Normal erythrocytes & Nontransfused AHA serum & 0 & 0 & 0 & 0 & 0 \\
Normal erythrocytes & Transfused AHA serum & 0 & 0 & +1 & +2 & +2 \\
AHA serum-sensitized & Antihuman globulin & +1 & +3 & +4 & +3 & +1 \\
normal erythrocytes & Antihuman globulin & +2 & +3 & +4 & +2 & +1 \\
$\begin{array}{l}\text { Coombs positive } \\
\text { patient erythrocytes }\end{array}$ & & & & & & \\
\hline
\end{tabular}


sitization or coating. These modifications have certain disadvantages because they may depend on alteration of the red cell surface or on high molecular substances used as suspending media. For example, a positive direct antiglobulin test may be obtained when the red cells are incubated with phenylhydrazine (7), upon exposure to heavy metals $(8,9)$ or when the red cell surface is altered by enzymes such as trypsin (10). Agglutination of erythrocytes in albumin-type media may be unrelated to erythrocyte sensitization (11). Many normal human serums have an auto-agglutinating property which has never been adequately explained (12). Silicates in colloidal solution may cause red cells to absorb serum protein in vitro and false positive antiglobulin reactions may occur (13). A positive direct antiglobulin test, therefore, does not necessarily imply that the reaction is immunologic in nature. IA occurred when the serum of patients who had received multiple transfusions was reacted with normal washed erythrocytes. It is probable that IA detected incomplete antibodies which had developed in response to weak erythrocyte antigens. These antibodies could not be detected during usual blood typing procedures and were not sufficiently reactive to cause a clinical transfusion incompatibility. Although isosensitization can occur following multiple transfusions, this is not the mechanism of the acquired hemolytic anemia secondary to neoplastic disease.

The presence of IA when antihuman globulin was reacted with experimentally or naturally sensitized erythrocytes was of considerable interest. Positive reactions were noted in antibody dilutions up to $1: 160$. In this type of IA reaction the globulin coating the red cell surface acts as antigen with the heterologous antibody in the Coombs serum. The major portion of the coating material which can be eluted from sensitized red cells appears to migrate electrophoretically with the gamma globulin fraction of the plasma proteins although alpha and beta globulins also may be found in the same eluate (14-16). After ultracentrifugation, the gamma globulins are present both in the $7 \mathrm{~S}$ fraction and in the 19S fraction (17) suggesting that these materials constitute a somewhat heterogeneous group. Most antihuman globulin serums now available include antibodies against the gamma and non-gamma globulin serum fractions (18), providing additional evidence that this IA reaction was antigen-antibody in nature.

There was an awareness during this study that the absence of IA when patient serums were reacted with their own or normal erythrocytes might perhaps be due to a noncomplement-fixing antibody not active in the IA system. Consequently, because it is incomplete, because it is demonstrable by antihuman globulin, and because it was thought not to fix complement, nonagglutinating anti-D was employed as a prototype antibody in an attempt to reconcile this problem.

The observation that IA did occur when incomplete (nonagglutinating) anti-D was reacted with appropriate erythrocytes was important for two reasons. First, it demonstrated, by IA at least, that this antibody does fix complement. In this regard it should be pointed out that failure to demonstrate complement fixation with prior assays may have been due to the relatively insensitive methods utilized for this determination. Although the IA technique has not been widely employed in clinical investigation, it is, nevertheless, a well known, well accepted, generalized immunologic phenomenon which will not occur in the absence of specific complement-fixing antibody (19). This method is more than ten times as sensitive as standard immunologic procedures now employed (20) and has detected antibodies against treponemes (1), bacteria (2), fungi (21), starch (21) and viruses (22). In addition, IA with incomplete anti-D, which resembles in certain limited respects the serum factors of this type of acquired hemolytic anemia, supports the assumption that antibody directed against erythrocytes was not present in the serum of these patients. This does not, of course, completely deny the existence of an antibody which is not detectable by this particular immunologic method.

The concept of auto-antibody formation $(23,24)$ has been invoked repeatedly to explain the pathogenesis of the serum factors responsible for acquired hemolytic anemia. This hypothesis is based on the following observations. The materials present in the serum may be gamma globulins (25) which behave in vitro to cause either direct or indirect agglutination of red cells with antihuman globulin. Also, these factors may be eluted from coated red cells in a fashion similar to that for antibody elution (26). It is believed that this 
serum auto-antibody becomes attached to red cells in vivo resulting in their premature sequestration and removal from the circulation $(27,28)$. This erythrocyte auto-antibody hypothesis has been strengthened by analogy to the experimental demonstration of auto-antibody formation to thyroid gland (29), lens (30), neurologic tissue (31) and sperm (32).

Although there are many similarities between acquired hemolytic anemia and auto-immune disorders, the analogy is not complete and there are a number of reasons which suggest that these abnormal serum factors are not erythrocyte autoantibody. In order to fulfill the strict criteria for antibody a factor must be shown to be an immunologic response of the organism to a specific antigen. Furthermore, this serum antibody must be shown to react with the original antigen (33). Experimental attempts to fulfill these requirements have either failed (34) or have been only partially successful (35-37). The ability of eluates from Coombs positive erythrocytes to produce active antiglobulin serum (38) and also to fully coat and sensitize all human erythrocytes (39) is recognized, but this does not necessarily establish an antigenic relationship with red cells. In addition, sensitization of normal red cells by concentrated eluates from a patient with Coombs negative acquired hemolytic anemia did not cause significant alteration of the in vivo survival of the red cells. On the other hand, when type D red cells were sensitized by the concentrated eluate from anti-D coated erythrocytes, such cells disappeared rapidly from the circulation and were sequestered in the recipient's spleen (40). The auto-antibody concept of disease has been extended clinically to include idiopathic thrombocytopenic purpura (ITP) and some leukopenic states. The association of acquired hemolytic anemia with ITP is not uncommon (41) and occasionally it has been reported with immunoleukopenia or immunopancytopenia (42). Although concomitant auto-antibody production to each of the formed elements of the blood may be possible, it seems highly improbable that this type of immune response would occur.

The failure to characterize the serum factors capable of red cell sensitization as erythrocyte antibody by the IA technique in these patients suggests that they are not the result of antigenic stimu- lation by red cells. However, an alternate hypothesis may be offered to explain this syndrome. In patients with lymphoproliferative and related disorders there may be an as yet undertermined, abnormal stimulus to or distortion of the antibodyproducing mechanisms of the body. This may allow the formation of certain globulins or factors, which may be antibody in nature, but whose antigenic relationships remain unrecognized. It has been demonstrated experimentally in animals that specific immunization is accompanied not only by specific antibody formation but also by the appearance of gamma globulins nonreactive with the original challenge (43-45). A clinical counterpart of this experiment may perhaps be seen in some patients with primary atypical pneumonia and infectious mononucleosis who reveal certain serologic abnormalities such as rising heterophile titers and biologically false positive tests for syphilis and who also develop transient acquired hemolytic anemia (46-49). Finally, to complicate this multi-faceted problem still further, the de novo synthesis of humoral antibody in patients with neoplastic disease is often impaired $(50,51)$, and yet it is this type of patient who not infrequently develops acquired hemolytic anemia.

The observations noted in this study do not disprove the auto-antibody hypothesis of acquired hemolytic anemia nor do they necessarily relate either to idiopathic acquired hemolytic anemia or acquired hemolytic anemia associated with other disease states, since these disorders have not been investigated. They do, however, provide additional support for the concept that these serum factors in lymphoma and leukemia are not erythrocyte auto-antibody $(52,53)$. It is suggested that these serum factors, having an affinity for the erythrocyte surface, may represent another manifestation of the dysproteinemic state.

\section{SUM MARY}

1. The purpose of this study was to determine whether the abnormal serum factors of acquired hemolytic anemia in patients with leukemia and lymphoma could be characterized as erythrocyte antibody by the immune adherence technique.

2 . The serum factors capable of red cell sensitization in these patients did not react as erythrocyte antibody in immune adherence. 
3. It is suggested that these factors, which have an affinity for the erythrocyte surface, may represent another manifestation of the dysproteinemic state.

\section{REFERENCES}

1. Nelson, R. A., Jr. The immune-adherence phenomenon. An immunologically specific reaction between microorganisms and erythrocytes leading to enhanced phagocytosis. Science 1953, 118, 733.

2. Nelson, R. A., Jr. The immune-adherence phenomenon. A hypothetical role of erythrocytes in defence against bacteria and viruses. Proc. roy. Soc. Med. 1956, 49, 55.

3. Coombs, R. R. A., Mourant, A. E., and Race, R. R. Detection of weak and incomplete $\mathrm{Rh}$ agglutinins: A new test. Lancet 1945, 2, 15.

4. Jandl, J. H., and Castle, W. B. Agglutination of sensitized red cells by large anisometric molecules. J. Lab. clin. Med. 1956, 47, 669.

5. Nelson, R. A., Jr., and Nelson, D. S. On the mechanism of immune-adherence. II. Analogy to mixed aggregation of sensitized antigens in the presence of complement; immune-adherence with animal platelets. Yale J. Biol. Med. 1959, 31, 201.

6. Coombs, R. R. A., Mourant, A. E., and Race, R. R. A new test for the detection of weak and incomplete Rh agglutinins. Brit. J. exp. Path. 1945, 26, 255.

7. Muirhead, E. E., Groves, M., and Bryan, S. Positive direct Coombs test induced by phenylhydrazine. J. clin. Invest. 1954, 33, 1700.

8. Sutherland, D. A., and Eisentraut, A. M. The direct Coombs test in lead poisoning. Blood 1956, $11,1024$.

9. Jandl, J. H., and Simmons, R. L. The agglutination and sensitization of red cells by metallic cations : Interaction between multivalent metals and the red-cell membrane. Brit. J. Haemat. 1957, 3, 19.

10. Wheeler, W. E., Luhby, A. L., and Scholl, M. L. L. The action of enzymes in hemagglutinating systems. II. Agglutinating properties of trypsinmodified red cells with anti-Rh sera. J. Immunol. 1950, 65, 39.

11. Dameshek, W. Acquired hemolytic anemia. Physiopathology with particular references to autoimmunization and therapy in Proc. Third Int. Congress of the Int. Society of Hematology. New York, Grune \& Stratton, 1951, p. 120.

12. Stratton, F., and Renton, P. H. Practical Blood Grouping. Oxford, Blackwell, 1958, p. 35.

13. Stratton, F., and Renton, P. H. Effect of crystalloid solutions prepared in glass bottles on human red cells. Nature (Lond.) 1955, 175, 727.

14. Fudenberg, H. H., and Kunkel, H. G. Physical properties of the red cell agglutinins in acquired hemolytic anemia. J. exp. Med. 1957, 106, 689.

15. Cutbush, M., Crawford, H., and Mollison, P. L. Observations on anti-human globulin sera. Brit. J. Haemat. 1955, 1, 410.
16. Young, L. E., and Miller, G. The long-term picture in autoimmune hemolytic disease. Trans. Ass. Amer. Phycns 1953, 66, 190.

17. Mollison, P. L. Factors determining the relative clinical importance of different blood-group antibodies. Brit. med. Bull. 1959, 15, 92.

18. Renton, P. H. Separation of Coombs reagent into two fractions. Nature (Lond.) 1952, 169, 329.

19. Turk, J. L. Immune-adherence with soluble antigens. Immunology 1958, 1, 305.

20. Woodworth, H. C. The Titration of Human Complement by the Method of Immune Adherence. Thesis, Graduate School of Yale University, 1958, p. 95 .

21. Brody, J. I., and Finch, S. C. Candida-reacting antibody in the serum of patients with lymphomas and related disorders. Blood 1960, 15, 830 .

22. Taverne, $J$. Immune-adherence of bacteriophage $T_{2}$. Brit. J. exp. Path. 1957, 38, 377.

23. Dameshek, W. Auto-immunization. Blood 1949, 4, 873.

24. Wiener, A. S., Gordon, E. B., and Gallop, C. Studies on autoantibodies in human sera. J. Immunol. $1953,71,58$

25. Dacie, J. V. Differences in the behaviour of sensitized red cells to agglutination by antiglobulin sera. Lancet 1951, 2, 954.

26. Komninos, Z. D., and Rosenthal, M. C. Studies on antibodies eluted from the red cells in autoimmune hemolytic anemia. J. Lab. clin. Med. 1953, 41, 887.

27. Doan, C. A., Wright, C. S., Wheeler, W. E., Bour oncle, B. A., Houghton, B. C., and Dodd, M. C. Some cyto-immunologic aspects of the hypersplenic syndromes. Trans. Ass. Amer. Phycns 1950, 63, 172.

28. Berlin, R. Red cell survival studies on normal and leukaemic subjects: Latent haemolytic syndrome in leukaemia with splenomegaly; nature of anaemia in leukaemia; effect of splenectomy. Acta med. scand. 1951, suppl 252, 1.

29. Witebsky, E., and Rose, N. R. Studies on organ specificity. IV. Production of rabbit thyroid antibodies in rabbit. J. Immunol. 1956, 76, 408.

30. Halbert, S. P., and Fitzgerald, P. L. Studies on the immunologic organ specificity of ocular lens. Amer. J. Ophthal. 1958, 46, no. 5, pt. 2, 187.

31. Kabat, E. A., Wolf, A., and Bezer, A. E. Studies on acute disseminated encephalomyelitis produced experimentally in rhesus monkeys. III. J. exp. Med. 1948, 88, 417.

32. Metalnikoff, S. Etudes sur la spermotoxine. Ann. Inst. Pasteur 1900, 14, 577.

33. Boyd, W. C. Fundamentals of Immunology, 3rd ed. New York, Interscience Publishers, 1956, p. 28.

34. Cajano, A., Miller, A., Finch, S. C., and Ross, J. F. Auto-immunization to blood cells. Sang 1955, 26, 141.

35. Liu, C. K., and Evans, R. S. Production of positive antiglobulin serum tests in rabbits by intraperi- 
toneal injection of homologous blood. Proc. Soc. exp. Biol. (N. Y.) 1952, 79, 194.

36. Desai, R. G., and Slifky, R. Experimental immunohemolytic anemia in AKR mice. Clin. Res. 1960, 8, 208.

37. Oliner, H., Schwartz, R., and Dameshek, W. Immuno-hemolytic anemia in runt disease. Clin. Res. 1960, 8, 214.

38. Komninos, Z. D., and Aksoy, M. Production of Coombs serums by injection of autoantibodies into rabbits. Amer. J. clin. Path. 1955, 25, 967.

39. Kidd, P. Elution of an incomplete type of antibody from the erythrocytes in acquired haemolytic anaemia. J. clin. Path. 1949, 2, 103.

40. Culp, N. W., and Chaplin, H., Jr. The effects of concentrated eluted anti-red blood cells antibodies on the in vivo survival of normal red blood cells. Blood 1960, 15, 525.

41. Evans, R. S., Takahashi, K., Duane, R. T., Payne, R., and Liu, C. K. Primary thrombocytopenic purpura and acquired hemolytic anemia. Evidences for a common etiology. Arch. intern Med. 1951, 87, 48.

42. Evans, R. S., and Duane, R. T. Acquired hemolytic anemia. The relation of erythrocyte antibody to activity of the disease; significance of thrombocytopenia and leukopenia. Blood 1949, 4, 1196.

43. Tiselius, A., and Kabat, E. A. Electrophoretic study of immune sera and purified antibody preparations. J. exp. Med. 1939, 69, 119.
44. Boyd, W. C., and Bernard, H. Quantitative changes in antibodies and globulin fractions in sera of rabbits injected with several antigens. J. Immunol. 1937, 33, 111.

45. Kabat, E. A., and Mayor, M. M. Experimental Immunochemistry. Springfield, I1l., Charles C Thomas, 1948, p. 177.

46. Aaron, R. S. Hemolytic anemia in viral pneumonia with high cold-agglutinin titer. Arch. intern. Med. 1952, 89, 293.

47. Hall, B. D., and Archer, F. C. Acute hemolytic anemia associated with infectious mononucleosis. New Engl. J. Med. 1953, 249, 973.

48. Florman, A. L., and Weiss, A. B. Serologic reactions in primary atypical pneumonia. J. Lab. clin. Med. 1945, 30, 902.

49. Moore, J. E., and Mohr, C. F. Biologically false positive serologic tests for syphilis. J. Amer. Med. Ass. 1952, 150, 467.

50. Dubin, I. N. The poverty of the immunological mechanism in patients with Hodgkin's disease. Ann. intern. Med. 1947, 27, 898.

51. Geller, W. A study of antibody formation in patients with malignant lymphomas. J. Lab. clin. Med. 1953, 42, 232.

52. Waksman, B. H. The toxic effects of the antigenantibody reaction on the cells of hypersensitive reactors in Cellular and Humoral Aspects of the $\mathrm{Hy}$ persensitive States, H. S. Lawrence, Ed. New York, Hoeber-Harper, 1959, p. 138.

53. Pirofsky, B. Correspondence. Blood 1960, 15, 555.

\section{ANNOUNCEMENT OF MEETINGS}

The Fifty-Third Annual Meeting of THE AMERICAN SOCIETY FOR CLINICAL INVESTIGATION will be held in Atlantic City, N. J., on Sunday afternoon and evening, April 30, 1961, in the Chalfonte-Haddon Hall (jointly with the AFCR); and on Monday, May 1, at 9:00 a.m., at the Casino Theater on the Steel Pier.

The Eighteenth Annual Meeting of THE AMERICAN FEDERATION FOR CLINICAL RESEARCH will be held in Atlantic City, N. J., on Sunday, April 30, 1961, at 9:00 a.m., at the Casino Theater on the Steel Pier. On Sunday afternoon and evening, April 30, 1961, a joint sectional meeting with THE AMERICAN SOCIETY FOR CLINICAL INVESTIGATION will be held in rooms in the Chalfonte-Haddon Hall.

THE ASSOCIATION OF AMERICAN PHYSICIANS will hold its Seventy-Fourth Annual Meeting in Atlantic City, N. J., at the Casino Theater on the Steel Pier on Tuesday, May 2, 1961, at 9:30 a.m., and in the Carolina Room, Chalfonte-Haddon Hall, on Wednesday, May 3, 1961, at 9:30 a.m. 